\title{
THE IMPACT OF MAQĀȘID AL-SHARĪ'AH ON ISLAMIST POLITICAL THOUGHT: IMPLICATIONS FOR ISLAM-WEST RELATIONS
}

\author{
Halim Rane*
}

\begin{abstract}
Although most of the more conservative, first generation Islamist political parties have experienced a decline in voter confidence in recent years, there has not been a commensurate decline in support for Islam to play a role in the politics of Muslim countries. In this context, a second generation of Islamicoriented (as opposed to 'Islamist') political parties have emerged which espouse a maqāșid-oriented approach in response to both domestic and international factors. Muslim political leaders have asserted such principles and goals as democracy, good governance, economic prosperity, socio-economic justice, human rights and pluralism as Islamic objectives. By establishing their policies on these objectives they have also attracted broader constituencies that include Muslims and non-Muslims, secularists and Islamists, and have eased some of the apprehensions Western governments have with Islam in Muslim politics.
\end{abstract}

\section{Introduction}

Over the past several decades, the study of international relations has taken a keen interest in political developments in the Muslim world and their implications for Islam-West relations. Much of the focus has been on the resurgence of Islam as a social and political force and particularly the rise of Islamist political parties. Infused with ideas about Islam as the solution to the social, economic and political problems of Muslim countries, the first generation of Islamist political parties were able to capitalise on a wave of post-colonial public frustration with the existing political order and a longing for stability, justice and prosperity envisioned through the implementation of the shari ${ }^{-} a h$ and the establishment of an Islamic state. In recent decades, Islamists have lost significant political ground to what Nasr, ${ }^{1}$ Bubalo, Fealy and Mason, ${ }^{2}$ and others have called 'Muslim democrats' - Muslim political

* Halim Rane is Deputy Director of the Griffith Islamic Research Unit and a Lecturer in the National Centre of Excellence for Islamic Studies at Griffith University, Australia. 
parties that do not pursue the establishment of a shari 'ah state but "viable electoral platforms and stable governing coalitions to serve individual and collective interests - Islamic as well as secular". ${ }^{3}$

For Nasr, 'Muslim democrats' include the Pakistan Muslim League (PML), Turkey's Justice and Development Party (AKP), and Malaysia's United Malays National Organisation (UMNO) - parties with a secular foundation (AKP excluded) that have come to occupy the centre of politics in Muslim countries by pragmatically integrating Muslim religious values into their political platforms. This strategy has attracted voters who previously supported Islamist political parties, while their secular foundation has enabled their pursuit of Islamisation policies without attracting the ire of Western governments.

For Bubalo, Fealy, and Mason, however, 'Muslim democrats' include Egypt's Muslim Brotherhood (MB), Indonesia's Prosperous Justice Party (PKS), and Turkey's AKP - parties that have not come from a secular origin and have adopted Muslim values for political expediency but have a genuine Islamic foundation and have genuinely internalised the principles of democracy. The long-standing assumption of Western policy makers that Islamists should be excluded from participation in politics because they will use the democratic process to ultimately impose theocracy ${ }^{4}$ is turned on its head by Bubalo, Fealy and Mason as well as others such as Irfan Ahmad ${ }^{5}$ who contend that democracy has actually transformed the ideology of such political parties as the MB, PKS, AKP as well as India's Jamaate-Islami respectively. Others have also discussed this phenomenon in terms of 'mainstream Islamists' - political parties or groups "that engage or seek to engage in the legal political processes of their countries and have publically eschewed the use of violence" - including Egypt's MB, Jordan's Islamic Action Front (IAF), and Morocco's Justice and Development Party (PJD) ${ }^{6}$

This article explores these emerging trends in political Islam more deeply and discusses their implications for Islam-West relations. It looks beyond Muslim democratic parties that have incorporated Muslim values as a pragmatic political tactic as well as Islamist parties whose political thought has evolved only to the stage of accepting democracy and rejecting the use of violence. This article's focus is on a second generation of Islamic-oriented political parties which, in response to internal and external forces, have distinguished themselves from first generation Islamists not only in terms of their broader political platforms but also in their approach to Islam. The politics and policies of second generation Islamic-oriented political parties demonstrate a maqāssid-oriented approach. These parties are Islamic in orientation and identity but regard democracy, economic prosperity, good governance, human rights, and pluralism as Islamic objectives, rather than the implementation of sharí 'ah law or creating an Islamic state in the modern, conventional sense. Also, unlike most of their first generation counterparts, second generation Islamic-oriented 
parties advocate positive relations with the West. Through their maqāșid-oriented approaches, they are not only redefining the concepts of Islamic democracy and political Islam but also the fate of Islam itself in the socio-political context.

This article draws on almost two decades of US foreign policy documents on political Islam and relations with the Muslim world as well as interviews conducted with key representatives of Turkey's Justice and Development Party (AKP), Malaysia's People's Justice Party (PKR), and Indonesia's Prosperous Justice Party (PKS). It begins with an overview of Islam-West relations drawing on salient implications of European colonial rule of the Muslim world as well as the post-colonial era. The article then examines US foreign policy on Islam and the Muslim world from the first policy document in 1992 until US President Barack Obama's landmark address on 'a new beginning' delivered in Cairo in 2009. It discusses the rise of the second generation of Islamic-oriented political parties in the context of the failure of the first generation, the revival of the maqāșid, and its implications for political Islam and relations with the West. The article contends that while the adoption of a maqāsid-oriented approach by certain Islamic-oriented political parties combined with a more accommodationist approach from Washington is likely to reduce confrontation between the United States and political Islam, tension between Washington and the Muslim world will continue so long as access to oil and support for Israel remain the two central pillars of US foreign policy.

\section{Islam-West Relations}

Throughout much of its history, Islam has displayed a strong syncretistic inclination, embracing and building upon the intellectual, institutional and infrastructural contributions of non-Muslim civilisations, including the Greeks, Romans, Persians, Indians, and Chinese. A dramatic reversal of this outlook came with the onset of European colonisation of the Muslim world. Since that time until today, Muslim perceptions of the West have been dominated by negative sentiments, confrontation, and suspicion. An aversion to values, norms, systems and institutions perceived as 'Western' has since been prevalent among Muslim masses. Colonisation left an intellectual legacy on both Muslim and non-Muslim thinking characterised by a view of the other as a distinct, contrasting and opposing entity. Orientalism, as termed by Edward Said, continues to have a profound impact on Islam-West relations not only in terms of Western perceptions of Islam, but also in the reverse. ${ }^{7}$

A popular perception among Muslims is that European colonial rule attempted to remove Islam from Muslim societies and replace an Islamic identity and culture with Western norms and values. The rise and success of Islamist political parties in Muslim countries is, therefore, seen by many Muslims as completing the process of independence from European colonial rule and achieving meaningful freedom. 
The parties that achieved independence from colonial rule and came to power were largely seen, in a cultural sense, as an extension of the former colonial rulers. For many Muslims, the process of independence was not complete and only the election of Islamic or Islamist parties that reflect the identity and values of the people would finally mark the country's true independence from colonisation. ${ }^{8}$

From the perspective of the majority of Muslims around the world, Islam can and should be part of the process of their democratisation. This includes the participation of Islamist parties in politics. A study conducted in 2009 by WPO, PIPA and CISSM found that the majority of Muslims interviewed support Islamist participation in politics. To the statement that "all people should have the right to organise themselves into political parties and run candidates, including Islamist groups" the majority in all countries surveyed agreed, including in Azerbaijan (75\%), Jordan (50\%), Indonesia (81\%), Palestine (69\%), Pakistan (83\%) and Turkey (53\%). Minorities of respondents agreed with the alternative statement that "Islamist groups should not be allowed to organise and run candidates because their ultimate goals are not consistent with democracy": Azerbaijan (24\%), Jordan (26\%), Indonesia (8\%), Palestine (30\%), Pakistan (16\%) and Turkey (30\%). ${ }^{9}$

With few exceptions, however, the United States has demonstrated a marked reluctance to accept Islamist political parties or even to engage with them. Only as a matter of political necessity has the United States accepted a role for Islamist parties, as in post-Saddam Hussein Iraq, in order to avert the intensification of civil strife and to construct at least a semblance of a representative government. The United States has also accepted the AKP in Turkey, a NATO member and until recently the lone friend of Israel in the region. Beyond these cases, the United States has had only limited engagement with even mainstream Islamists such as Jordan's IAF and Morocco's PJD. ${ }^{10}$ In other cases, such as Egypt's MB and Hamas in Palestine, US engagement is stifled by Egypt and Israel's self-serving arguments that lifting the restrictions and restraints on such groups would endanger stability and security in the region. ${ }^{11}$

The reassertion of Islamic identity among Muslims and the re-emergence of Islam as a social and political force over the past several decades has been met by the West with concern and even perceived as a threat. The perceived Islamic threat is in terms of stability of allies and security of access to vital resources, but it is also a matter of ideology. The role that Muslims envision for Islam in politics goes against the grain of the secularising mission of modernity. The infusion of Islam in the politics of Muslim countries, otherwise referred to as political Islam, runs "counter to the entire modern history of the Western tradition of secularising revolutions" 12 and represents "a divergence and/or infringement upon neutral secular public space, as a throwback to pre-modern forms of Muslim political order". ${ }^{13}$ The central concern or threat has come from political Islam's call for an Islamic state based on the 
implementation of the shari $a h$. The uncertainty as to what this precisely means has created extensive anxiety among Western policy makers.

Ideological factors have been evident since the West's first major encounter with political Islam in the modern era: the overthrow of the Shah of Iran (then a key Western ally in the Middle East) by revolutionary Islam and the establishment of the Islamic Republic of Iran in 1979. Americans have historically been alarmed by revolutions in general due to their radical nature and the inherent challenge they present to the status quo based on order and the predominance of the United States. Foreign-policy elites in the United States have, therefore, displayed "hostility toward revolutions that have diverged from the American constitutional, liberal, and capitalist norm". ${ }^{14}$ In the case of Iran's Islamic revolution, security concerns were not foremost in the minds of US policy makers, but rather, the challenge it presented to the 'existing order' and the clash of worldviews it represented: 'Islamic-theocratic' versus 'Western-secular'. ${ }^{15}$ The Carter administration, in power at the time, regarded the idea of an Islamic state to be "absurd" as it "ran counter to the entire modern history of the Western tradition of secularising revolutions". ${ }^{16}$ Carter's response is indicative of the West's perception at the time that secularism had become a global norm and religion was no longer relevant in politics. At the same time, Islamist groups, Shi'ite as well as Sunnite, were celebrating Iran's Islamic revolution, which became a source of inspiration for Muslims globally. ${ }^{17}$

The 1980s passed with a deterioration in relations between the United States and Iran. Washington sought to contain the Islamic revolution based on a fear of it spreading through the Middle East and used Iraq under Saddam Hussein as a bulwark. However, during the subsequent Reagan administration, the United States was still without a defined policy on political Islam. US policy makers tended to regard the new phenomenon opportunistically. On the one hand, Iran was perceived as a threat and enemy, but on the other, jihadist forces or mujahedeen (Arab.: mujahidūn) in Afghanistan and Islamists in Indonesia were used in proxy wars against the Soviet Union and the spread of communism. The case of Afghanistan, in particular, demonstrates not only the pragmatism of US policy at the time in supporting the mujahedeen but also the priority given by US foreign policy to realism over moralism - or strategic matters over and above such principles as democracy and human rights.

\section{The Islamic State}

The idea of an Islamic state characterised by the implementation of the sharī $a h$ is a modern phenomenon developed by Abū 'l-A 'lā Mawdūdī (d. 1979) in the context of British colonialism and the identity politics of the Indian subcontinent in the years preceding partition. In response to Muslim League calls for a Muslim state of 
Pakistan, Hindu calls for a secular India, and communist calls for a socialist state, Mawdūdī perceived a threat to the Islamic identity and called for the establishment of 'Allah's government', hukümat-i ilāhiya or an Islamic state. ${ }^{18}$ Although the concept became a central pillar of Islamists across the Muslim world by the latter half of the twentieth century, so without foundation in Islamic thought was his Islamic state that Mawdūdī initially struggled to convince the Indian 'ulamā' and those in his own party of its legitimacy. He was forced to engage in an elaborate reconceptualising of the concepts of God, Lordship, worship, and religion in relation to politics in order to lay the theological foundations for his case. ${ }^{19}$

Mawdūdī's concept of an Islamic state found support among other influential Islamic thinkers and leaders. Along with Mawdūdī, Sayyid Quṭb (d. 1966) in Egypt, and Ayatollah Khomeini (Rūḥ-Allāh Khumaynī, d. 1989) in Iran popularised the vision of an Islamic state among Muslim masses globally and made it the central pillar of the Islamic resurgence of the late twentieth century. In the context of Southeast Asia, for instance, Kamal Hassan remarks that several factors contributed significantly to the spread of the concept of an Islamic state including the translation of Mawdūdī's and Sayyid Quṭb's work into Malay, Indonesian and English where Muslim students studying in the West encountered such writings through the Muslim Student Associations on their university campuses; the adoption of Mawdūdī's and Sayyid Quṭb's books as required reading by such institutions as the International Islamic University Malaysia; and the adoption of their ideas among Muslim youth movements such as ABIM and political parties such as PAS. Hassan finds "clear influence of Maududi's ideas" on PAS, particularly the concepts of Islamic state and God's sovereignty. ${ }^{20}$

Amid the ascendency of the concept of the Islamic state as envisioned by Mawdūdī, Sayyid Quṭb, and Khomeini, Islamic scholars of political science were already questioning the vision. Louay Safi cautioned as early as 1991 that Muslims were confusing the concept of state with that of ummah. He contends that an Islamic state is one in which "legal order is based on and derived from the principles of the shariah", which he adds "should not, however, be interpreted to mean that the Islamic state's purpose is to impose a narrowly defined code of behaviour on society". ${ }^{21}$ In terms of legislation, the domain of the state is to regulate individual behaviour in relation to the society as a whole or what might be termed mașlahah mursalah (public good), while matters of morality and worship (akhlāq and 'ibādāt) as well as the regulation of behaviour between members of society ( $m u$ ' $\bar{a}$ malāt) fall within the domain of the ummah or civil society. Thus, the purpose of the Islamic state is to "facilitate the realisation of the human mission [...] to coordinate the activities of the ummah in ways that will enable a society to cope with economic and political challenges and to enhance the quality of life in the community". ${ }^{22}$ It is the pursuit of these objectives within the framework of shari 'ah that makes 
a state 'Islamic'. However, the legitimacy of the state is derived from the will of the ummah, including the 'ulama', which historically controlled or at least held influence over judicial, educational and social institutions and thereby the power to enact law remained the domain of the people rather than the ruler. Moreover, as the legitimacy of the state depends upon the extent to which its organisation and power reflects the will of the ummah, Islamic legitimacy is conferred upon political systems based on elected representative rule. ${ }^{23}$

\section{Islam in Muslim Politics}

Not only did the first generation of Islamist political parties fail to deliver on good governance and socio-economic advancement in accordance with the expectations of the masses but their approach, rhetoric and policies attracted distrust and opposition from a range of constituencies including secularists, moderate Muslims, and non-Muslim minorities as well as Western governments. The twenty-first century has witnessed those labelled as Islamists lose considerable political ground to more centrist Muslim political parties that have incorporated Muslim values into their political programme or have otherwise Islamised certain public policies. The work of Nasr, for instance, documents this trend in the context of Pakistan in 1997, Bangladesh in 2001, Turkey in 2002, Indonesia in 2004 and Malaysia in 2004. He rightly identifies that those most likely to attract the Muslim vote are parties that successfully "integrate Muslim values and moderate Islamic politics into broader right-of-centre platforms that go beyond exclusively religious concerns". ${ }^{24}$

In Malaysia, for instance, Abdullah Ahmad Badawi won a landslide victory over PAS in the 2004 elections. UMNO won 50 per cent of the seats and the Barisan Nasional coalition led by UMNO won 90 per cent of the seats. PAS, however, managed to secure only 3 per cent of the seats in Parliament. This can be attributed to a combination of two decades of Islamisation policies and economic prosperity under former Prime Minister Mahathir Mohamad along with Abdullah's personal Islamic credentials, education, and Islam Hadhari policy. ${ }^{25}$ This marked a reversal of the previous election in 1999 when PAS was able to capitalise on the discontent among Malay voters over perceived corruption of the Mahathir government and particularly the perception of unjust mistreatment of Anwar Ibrahim by the government and judiciary, increasing the party's seats in parliament from 8 to $27 .{ }^{26}$ In the most recent 2008 elections, PAS won 14 per cent of the vote, increasing its seats in parliament to 23 .

However, this cannot be interpreted as a shift back to conservative Islam among Malay voters. On the one hand, Abdullah's Islam Hadhari came under criticism from the opposition PAS party which carried some weight among Malay voters. ${ }^{27}$ More importantly, though, the once-dominant 'ulama' 'among PAS' leadership have 
been offset by a new generation of educated, professional and pragmatic leaders. ${ }^{28}$ They have been instrumental in the party dropping its rhetoric about an Islamic state, engaging with non-Muslim voters, and joining the People's Front coalition with the PKR and DAP based on a multi-ethnic platform. ${ }^{29} \mathrm{PKR}$ is internally discordant with the DAP (Democratic Action Party), a Chinese party with no Islamic credentials, having a lead role in the coalition. Writing in 2006, PKR's advisor and (unofficial) leader Anwar Ibrahim advocated a maqāssid-oriented approach which he thought was in contrast with the more literal approach historically displayed by PAS.$^{30}$ It is also noteworthy, however, that the new generation of PAS leadership, including the Deputy President Nasharuddin Mat Isa, endorse a maqāsid-oriented approach, ${ }^{31}$ although the party still adheres to the vision of establishing an Islamic state in the modern conventional sense characterised by the implementation of shari ${ }^{-} a h$ laws. ${ }^{32}$

Moreover, even while Islamists were enjoying some political successes in the 1990 s, their victories came amid discussion about the failure of political Islam. ${ }^{33}$ The two central counts concerning the failure have been political Islam's inability to provide an effective blueprint for an Islamic state based on the sharī 'ah and the abandonment of the pan-Islamic or caliphate model and contentment with a world order based on nation-states. ${ }^{34}$ However, this is largely a failure only to the extent that it has not met the vision of Mawdūdī and Sayyid Quṭb. The real failure is that political Islam has not met the basic qur'ānic vision of establishing a just and equitable social order. ${ }^{35}$ The implementation of the shari ${ }^{-} a h$ should not be seen as the yardstick for the success of political Islam. Even when the shari 'ah (in its modern, conventional conception) is fully or near-fully implemented, as in the case of Afghanistan under the Taliban, Iran, Pakistan, Saudi Arabia, or Sudan, the state has not fulfilled basic Islamic ideals as discussed by the late Fazlur Rahman (d. 1988), Louay Safi and others. Rather, such states are among the poorest in terms of performance on key social, economic and political measures. No positive correlation is observable between a more full or comprehensive implementation of the $\operatorname{shar}_{\bar{l}}$ 'ah and progress towards a more just and equitable social order in terms of human, gender and minority rights; political participation and stability; good governance and government accountability and transparency; economic advancement; equitable distribution of wealth; educational attainment; and national power. ${ }^{36}$ In large part, the problem is that these values, goals and standards are not the emphasised priorities of the modern conventional conception of the shari ${ }^{\prime} a h$. Rather, they are often associated with the West, devalued, dismissed by Islamists and not included as part of the Islamic agenda. ${ }^{37}$

The first generation of Islamist political parties that based their political programme on issues of public morality, the implementation of hudüd laws, and establishment of Islamic states have lost the confidence of the Muslim electorate due to their lack of effective response to the major social, political and economic problems 
of Muslim countries; their inability to connect with non-Muslim minorities and secularists; and the suspicion and concern they evoke among Western powers. Today, Muslims do not necessarily vote on the basis of religious identity but according to their values and interests. If Islam is to contribute positively to society and state an alternative approach is needed that is inspired by or derived from Islam and integrates democratic political institutions that have been most successfully developed by Western nations. ${ }^{38}$

\section{US Foreign Policy}

A defined US foreign policy on political Islam did not emerge until 1992 during the administration of Bush Senior. To put this development into context, by that time Islamist political parties were already in power in Sudan via a military coup; making significant electoral gains in Egypt, Jordan, and Tunisia; and had won the parliamentary elections in Algeria where civil war had erupted in response to a military coup to prevent the democratically elected FIS party from taking power. Additionally, the mujahedeen in Afghanistan were claiming victory against the world's other superpower, the Soviet Union, and secular Iraq had failed to dislodge Islamic rule in Iran as hoped by Britain and the United States. Further, Islamist opposition groups in Indonesia were becoming more vocal against the secular regime of Suharto, pushing him to pursue Islamisation policies, while in Malaysia, Mahathir was countering the Islamist challenge posed by PAS with Islamisation policies of his own which included the establishment of Islamic banks, the International Islamic University Malaysia, and the national halāl certification regime.

In June 1992, the then Assistant Secretary of State, Edward Djerejian, delivered an address at Meridian House entitled "The United States, Islam, and the Middle East in a Changing World". The document is framed in a post-Cold War context with Russia as a partner in the new world order. Two major goals of the United States in the Near East are articulated as: (1) "a just, lasting and comprehensive peace between Israel and all her neighbours, including the Palestinians"; and (2) "viable security arrangements which will assure stability and unimpeded commercial access to the vast oil reserves of the Arabian Peninsula and Persian Gulf"' ${ }^{39}$

About half-way through the document, a third pillar of US policy is added: "support for human rights, pluralism, women's and minority rights, and popular participation in government and our rejection of extremism, oppression, and terrorism". ${ }^{40}$ The factors that underpin this policy are listed as "diversity", "interaction", and "common aspirations". The United States would relate to others on the basis of understanding and tolerance, accepting differences in values and interests; working across a range of fields including political, economic, social, cultural, and military; and recognising the need for cooperation to realise common goals. The United States pledges its 
support to those parties that share its fundamental values of "steps towards free elections, creating independent judiciaries, promoting the rule of law, reducing restrictions on the press, respecting the rights of minorities, and guaranteeing individual rights". ${ }^{4}$

The document also emphasises that the foreign policy of the United States is neutral in terms of religion; that religion is not a determinant, positive or negative. It makes clear that the United States differs with those,

regardless of religion, who engage in terrorism, oppress minorities, preach intolerance, or violate internationally accepted standards of conduct regarding human rights; who are insensitive to the need for political pluralism; who cloak their message in another brand of authoritarianism; who substitute religious and political confrontation for constructive engagement with the rest of the world; who do not share our commitment to peaceful resolution of conflict, especially the Arab-Israeli conflict; and who would pursue their goals through repression or violence. ${ }^{42}$

It is noteworthy that the address was not matched by a corresponding policy shift and that the "liberal themes in Djerejian's speech were not translated into practical policy guidelines" as "American officials were reluctant to apply the new discourse while formulating American foreign policy". ${ }^{43}$ Fawaz Gerges comments that the Bush Senior administration "did not exert any pressure on its traditional Muslim clients to open the political process, accommodate the opposition, and expand popular participation in government". ${ }^{44}$ However, the document did establish a broad and positive framework that set a benchmark that was reiterated by succeeding administrations.

During the Clinton era, a number of policy statements concerning Islam-West relations and political Islam were issued. Certain key points were reiterated including that the United States was not hostile towards Islam but towards violence and terrorism, there is essential harmony between Islamic and Western values, and encouragement for Muslim states to emulate Turkey and Pakistan rather than Iran and Sudan. The Clinton administration was indifferent to Islamists in the main, provided their focus was on domestic issues and not concerned with matters that would negatively impact on US national interests. Gerges notes that "most Clinton administration officials stressed their concern with the potential implications of Islamists' foreign-policy agenda, not their internal politics" ${ }^{45}$ Additionally, like those in the era of Bush Senior, Clinton officials held the view that political Islam is a consequence of a lack of economic, educational, and political opportunities in the Muslim world rather than a product of Islam per se.

However, in a major address on political Islam to the Washington Institute for Near East Policy delivered in May 1994, Clinton's National Security Advisor, Anthony Lake, expressed the challenge in the Middle East in terms of a clash 
between the forces of good and evil. ${ }^{46}$ While the Clinton administration did not always accept the claims of Israel, Egypt, and Algeria that mainstream Islamists were engaged in terror, policy makers at the time failed to distinguish between Islamists committed to the ballot and those who carried out violence. Gerges finds that this generalisation of Islamists contributed to "the ambiguity in United States policy statements on political Islam", ${ }^{47}$

In its declarations of a war on terror, the Bush Junior administration offered repeated reassurances that the United States was not at war with Islam. ${ }^{48}$ However, the invasion and occupation of Iraq and Afghanistan undermined the Muslim world's confidence and trust in the United States. Moreover, the failure of the United States to defend the outcome of democratic elections in Palestine in 2006 reinforced the reputation of the United States as having double-standards on the issue of democracy in the Muslim world. Similarly, the cases of torture at United States-run prisons in Abu Ghraib, Bagram, and Guantanamo Bay resulted in the dismissal of United States rhetoric about human rights as hypocrisy.

The Obama administration has arguably made significant efforts to mend IslamWest relations. His inauguration address announced a new beginning: "To the Muslim world, we seek a new way forward, based on mutual interest and mutual respect" 49 and his first overseas address was delivered in the parliament of Turkey, a secular Muslim nation located at the crossroads of Europe and the Middle East, with a democratic government that both respects and reflects the Islamic values of the Turkish people.

The defining speech, however, was Obama's address on a 'new beginning' with the Muslim world delivered at Cairo University in June 2009. Among the most important dimensions of this address was its acknowledgement of past wrongs and grievances and its placing Islam-West relations in context. ${ }^{50}$ Obama clearly articulates his vision for the future on the basis of "mutual interest and mutual respect, and one based upon the truth that America and Islam are not exclusive and need not be in competition. Instead, they overlap, and share common principles principles of justice and progress; tolerance and the dignity of all human beings." 51

He outlines seven sources of tension, issues that the Muslim world and the West must confront together: violent extremism, the Israel-Palestine conflict, the proliferation of nuclear weapons, democratisation, religious freedom, women's rights, and economic development and opportunities. In terms of US engagement with political Islam, Obama's Cairo address did set out some general principles. It states that the United States does not seek to impose any political system but that all people desire a government that allows freedom of expression and political participation, upholds the rule of law and an equitable judiciary, adheres to standards of accountability and transparency, and generally respects human rights. 
However, this US administration does not support the participation of 'Islamists' in the political process of Muslim countries. A realist perspective of international politics continues to prevail in Washington which seeks to maintain the status quo, however unprincipled it may seem, rather than risk the possibility of jeopardising the two central pillars of US foreign policy - access to oil and support for Israel. A notable exception to this position is Turkey. Does the United States' acceptance of the AKP in the aftermath of the party's electoral victories in 2002 and 2007 indicate a shift in US foreign policy given that the AKP is widely seen as Islamic in orientation in spite of its self-identification as a conservative democratic party? Alternatively, has the AKP found the acceptable approach to Islam that appropriately balances Islamic values with secular democratic principles? Or is Turkey of sufficient strategic importance to the United States that values and principles are irrelevant?

\section{The Maqāṣid Revival}

There is a maturing of US foreign policy towards political Islam under Obama which coincides with the emergence of a second generation of Islamic-oriented political parties that are not inherently secular and have adopted Muslim values and Islamised public policies for pragmatic political purposes. Nor are they Islamist and have adopted democracy as a political tactic. Parties such as Turkey's AKP and Indonesia's PKS are developing politics based on a maqāșid-oriented approach by which democracy, good governance, economic prosperity, socio-economic justice, human rights and pluralism are regarded as Islamic objectives. Malaysia's PKR faces opposition from one of its coalition members, DAP, in taking an Islamic platform over issues of governance, although its other coalition member, PAS, is a strong advocate of Islamic government. A maqāssid-oriented approach is essentially goal-oriented and holistic. As opposed to reading verses of the Qur'ān in isolation, the maqāssid approach requires a comprehensive reading of the text as an integrated whole in order to identify the higher objectives and then interpreting particular verses on a given topic according to the identified maqāssid or objectives, intent or purpose..$^{52}$

Since the turn of the century, an emerging trend among Islamic intellectuals has been the adoption of a maqāsid-oriented approach as a means of articulating the essence and objectives of Islam in response to contemporary conditions and realities. The first major contribution to the maqāșid in the modern era was Muhammad al-Ṭāhir Ibn 'Āshūr's Maqāṣid al-sharī at al-islāmiyyah, first published in 1946, which was translated into English and republished in 2006. Also recently published are a number of books on Abū Isḥāq al-Shātibī’s theory of maqāṣid including Muḥammad Khālid Mas 'ūd's Shatibi's Philosophy of Islamic Law and Ahmad Raysūnī's Imam al-Shatibi's Theory of the Higher Objectives and Intents of Islamic 
Law. Contemporary scholars including Kamali, Ramadan, Baderin, and this author have also discussed the maqāssid approach in reference to Islamic legal thought, human rights, jihād and conflict resolution. ${ }^{53}$

The maquasid can be traced back to the administrative approach of the second caliph, 'Umar b. al-Khațāāb (r. 634-644) and the Mālikī 'school' of Islamic jurisprudence, which emphasises public interest or mașlahah. ${ }^{54}$ The concept of maqāssid was developed by the eleventh-century theologian Abū Ḥāmid al-Ghazālī (d. 1111) in reference to five fundamental protections: life, religion, property, progeny, and intellect. However, this conception was revised and expanded in the fourteenth century by Ibn Taymiyyah (d. 1328) and was developed as a new philosophy of Islamic law by Abū Isḥāq al-Shāțibī (d. 1388).

In fact, the expansion of maqāșid beyond al-Ghazâlī's conception began with 'Izz al-Dīn 'Abd al-Salām's (d. 1261) work on the qawā'id al-aḥkām or 'legal maxims', which broadened the discussion of maqāssid in terms of promoting benefit and preventing harm. Maqășid was then expanded in the fourteenth century by Ibn Taymiyyah, who identified a more open-ended list of values that included fulfilment of contracts, preservation of kinship ties, honouring the rights of one's neighbours, sincerity, trustworthiness and moral purity. He objected to the essential objectives of Islamic law being limited to the five maqāssid expounded by al-Ghazālī, stating that these five or six do not represent the highest or most significant of objectives. The work of al-Shātibī, however, made a profound contribution to developing the theory of maqāṣid by focusing on the concept of mașlahah, or 'public interest', as an approach to overcoming the rigidity imposed by literalism and qiyās (analogy). The maqāșid theory of al-Shāțibī is based on an inductive reading of the Qur'ān in order to identify the higher objectives, intent and purpose of the divine laws, which are intended to preserve human interests in both this world and the next.

In the modern era, Ibn 'Āshūr's (d. 1973) Maqāṣid al-sharī'ah al-islāmīyah is arguably the most important attempt of the twentieth century to further develop the theory of maqāsid. Expressing the need for an objective-based approach to Islamic law in light of modern realities, he introduces to the theory of maqāsid the preservation of the family system, freedom of belief, orderliness, natural disposition, civility, human rights, freedom and equality as objectives of Islamic law. In contemporary times, Yūsuf al-Qaraḍāwī has further extended the maqāsid list to include social welfare support, freedom, human dignity and human fraternity, while Mohammad Hashim Kamali has added to this list the protection of fundamental rights and liberties, economic development and research, and development in science and technology. Kamali contends that the maquassid remains dynamic and open to expansion according to the priorities of every age..$^{55}$

In order to understand the current maqa assid revival, the socio-political context of its development in the fourteenth century should be explained. The thirteenth 
century was a period of turmoil for the Muslim world, particularly for those regions that suffered the invasion of the Mongols. By contrast the fourteenth century was a period of relative peace and political stability that allowed intellectual activity to resume. Much of this work sought to re-evaluate tradition in light of the social, political, financial, commercial, and religious changes that had occurred. ${ }^{56}$ Mas $\mathrm{u}$ ud discusses these changes in some detail and summarises their impact on legal thought as follows:

The spread of Sufi tariqas had contributed to idleness and an exaggerated ideal of Islamic piety that constricted the concept of legal obligation. The influence of Razism increased the influence of Shafi'i and Ash'ari schools of thought. The establishment of the madrassa system promoted education and widened its scope. The economic changes, especially the new developments in the Mediterranean trade, challenged the Andalusian Maliki legal concepts and theories on trade and commerce. In a number of situations, the new trade practices came into apparent conflict with the prevailing doctrines of Islamic law. ${ }^{57}$

With dramatically changing realities and conditions over a 1,400-year history, the challenge for Muslims has been to develop an approach to the law that would ensure its continued relevance and vibrancy. During the formative years of Islamic law, the eighth to the tenth century, jurists could have a wider degree of confidence in a methodology that relied heavily on qiyās. In a critique of the continuity of this approach, AbdulHamid AbuSulayman writes that due to their close proximity to the time and space of the Prophet, the classical jurists could, to a greater extent, engage in literalism and be somewhat confident in analogy as a reliable methodology. However, "when contemporary jurists function in the same manner and even repeat the old instructions word for word, there is obviously a lack of appreciation for the changes that have taken place". 58

Like the twelfth and thirteenth centuries, the nineteenth and twentieth centuries had a profound impact on the Muslim world on account of the significant and lasting impacts of European colonial rule - psychologically, socio-culturally, economically, and politically. It left a legacy of anti-Western sentiments, fragmentation of legal codes, inter-religious and inter-ethnic conflict, poverty and underdevelopment, and unrepresentative authoritarian rule. ${ }^{59}$ The struggle to reassert an Islamic identity in the context of society and state gave rise to political Islam and the concept of the Islamic state based on the application of shari 'ah as the state's law code. The popularity of Islamists with Muslim masses prompted secular ruling elites to appeal to Islam with various gestures and policy initiatives. While this phenomenon pushed Muslim societies in the direction of Islamisation, Islamic political thought did not advance much beyond the original conceptions of Mawdūdī and Sayyid Quțb aside from the general embracing of democratic political participation and rejection of violence for political means. The failure of the conventional vision to sufficiently 
address the needs, aspirations, and expectations of Muslim electorates along with the declining electoral success of Islamists encouraged a maturation of Islamic political thought which has seen the emergence of a second generation of Islamic-oriented political parties that espouse a maqāssid-oriented approach.

\section{Islamic-Oriented Political Parties: The Second Generation}

The role of maqășid in political Islam has not been driven by the 'ulamā' or even Islamic intellectuals. Rather, this phenomenon can be attributed to Islamic-oriented political leaders like Anwar Ibrahim and Recep Tayyip Erdoğan. Their approach to politics and policies have been accepted by Muslims as Islamically legitimate largely on account of their personal qualities, their sound Islamic credentials, involvement in various Islamic groups and movements, and their personal commitment to the Islamic faith. That these leaders have developed an Islamic politics of the kind that characterises their respective parties is highly significant in terms of the trajectory of political Islam.

A maqāssid-oriented approach can be observed among Turkey's AKP, Malaysia's PKR, and Indonesia's PKS. It should be highlighted that the AKP does not regard itself as Islamist or even Islamic but rather a conservative democratic party. PKR has also not declared itself as an Islamic party. However, Islamic beliefs and values are a deeply important part of the identity of most Turkish people and the success of the AKP in Turkey is due to the fact that this party and its leadership respects and reflects the beliefs and values of the people. Its political programme is not focused on the issues of implementing hudūd laws or establishing an Islamic state in the modern conventional sense, but issues of greater substance and centrality to Islam. Turkey's constitution does not permit political parties on the basis of religion or ethnicity, and as demonstrated by successive military coups that have removed Islamist parties from power, the secular constitution is staunchly defended by the military in Turkey. While the AKP is restrained by the Turkish constitution and military from openly defining itself as an Islamic party, according to experts "Islamic ideas and an Islamic worldview are still included in the identity of its leadership and might also be included in the AKP's deep-seated philosophy" ${ }^{60}$ In this sense, the AKP exhibits a maqāsisid-oriented approach, although the party does not and cannot use the term. Individual members of the party acknowledge the consistency between their party's policies, Islam's higher objectives, and what have become universal norms and ideals. ${ }^{61}$

The AKP came to power in 2002 winning 34 per cent of the vote. Proving its democratic credentials, the AKP held scheduled elections in 2007 and achieved an overwhelming victory winning 47 per cent of vote. The party has a comprehensive and progressive political programme that covers fundamental rights and freedoms; 
the economy; public administration; foreign policy; and social policies that include education, culture and art, health, social security, labour, equal participation and rights for women, family and social services, youth and sports, urbanisation and housing, environmental protection, science and technology, written and visual media, and road safety. The AKP aims to achieve its political programme through the promotion of universal rights and freedoms; addressing Turkey's social, economic and administrative problems; mobilising the country's human and physical resources; raising living standards of all and reducing the income distribution gap; supporting civil society and including non-governmental organisations in public administration; and ensuring public sector transparency and accountability. ${ }^{62}$

With respect to foreign policy, the AKP recognises Turkey's strategic location between the Middle East and Europe and seeks to maintain positive relations with both. ${ }^{63}$ The AKP sees Turkey as an important contributor to the security and stability in the region and increasingly central to more positive relations between Islam and the West. The AKP is committed to achieving Turkey's membership in the European Union ${ }^{64}$ and maintaining the country's importance within NATO. It seeks to maintain Turkey's positive relations with the United States, expanding the relationship from one based primarily on defence cooperation to also include economic matters, investment, science and technology. Simultaneously, the AKP desires positive relations with the Russian Federation, China, Southeast Asia and the Middle East. ${ }^{65}$

Certain political parties in other Muslim countries that do not face the same constitutional constraints as Turkey's AKP are more overt in their commitment to a maqāssid-oriented approach. Unlike Turkey's AKP, which is the ruling party, parties such as Malaysia's PKR and Indonesia's PKS have never formed a government, but they are proposing policies that advance justice, human rights, education, government accountability and transparency and economic development, which they regard as the maqāsid or higher objectives of Islam. In Malaysia's most recent elections in 2008, the PKR won 19 per cent of the vote, 31 of the 222-seat Parliament. In Indonesia's most recent elections in 2009, the PKS won 8 per cent of the vote, 57 seats of the 550-seat Parliament, and as part of the governing coalition the party has four ministers in the government.

This writer's interview with a PKR member in Kuala Lumpur indicated that the maqāsid-based overtures of this party differentiates it from the first generation of Islamist parties in that service to the people - such as education for the people, health care, and welfare services - takes a more prominent place in the party's official objectives ${ }^{66}$ Similarly, the maqāsid approach is central to the politics of the PKS in Indonesia. In the words of Luthfi Hasan Ishaaq, president of the party, "the international community is now concerned about the [issues] similar to the maqāsid, the universal values. It's time to declare the original objectives of Islamic teaching 
[...] the maqāssid sharì 'ah. We are now moving to that." He goes on to explain that the main priorities of the PKS are education, public service, health care, income levels, and the standard of living. ${ }^{67}$

The advocators of maqāșid argue that Islam is consistent with good governance and socio-economic development and have shown that such an approach is attractive to a broad constituency that includes non-Muslims as well as Islamists. The maquașid is gaining ground among Islamist political parties because "the traditional approach has failed and secondly [because of] pressures from the realities of non-Muslims $[\ldots]$ we are now living in a very globalised world and it is inter-connected with other parts of the world". ${ }^{68}$

PKS president Ishaaq is critical of such countries as Sudan, Pakistan, and Afghanistan that adopt the title of 'Islamic state' and argues that "it is not necessary to have the name [Islamic state] but move to develop, to serve the interests of the communities of the nation [...]. Just serve the nation, the basic needs should be fulfilled, the services should be provided. This is Islam. ${ }^{\circ 69}$ Another advocate of the maqāṣid-oriented approach adds that the maqāṣid is the best approach as it can be easily understood not only by the Muslims but by the non-Muslims alike. If you approach from a fundamentalist angle then it becomes very difficult to explain. ${ }^{70}$

\section{Implication for Political Islam and Relations with the West}

In addition to providing the scope and flexibility to effectively operate amidst diverse and competing internal social forces, the maqāșid approach also advocates to avoid objection from external forces that generally hold pejorative views and are suspicious of Islamic-oriented parties. PKS president Ishaaq acknowledges that Western countries such as the United States and Australia are better able to identify with parties such as the PKS that adopt the universal values enshrined in the maqassid than the first generation Islamists that retain literalist views of shari 'ah and an Islamic state. The Islamic values derived from a maqāsid perspective, he explains, as "al-Ma' $r u f$, the acceptable values [that] everybody will accept even if they don't believe in God". 71

However, a maqāșid approach does not necessarily translate into a wholesale adoption of policies that are conciliatory or compatible with the West. The one issue that even second generation Islamic-oriented political parties remain at odds with the United States is the Israel-Palestine conflict. In large part, this is due to an internalisation of and commitment to such principles as a just peace, freedom and independence. Former MP and founding member of the AKP in Turkey, Hüseyin Kansu, explains that "what we want in the region and in the world is peace and serenity [...]. Israel should leave all those areas occupied after the 1967 war - the Golan Heights, West Bank, Jerusalem and Gaza Strip. Still they control Gaza. Israel 
should leave all these lands and Palestine must be an independent state. Both Israel and Palestine must respect their borders, and peace should come to the region; they should live in a civilised way." He regards the question of Palestine as the foreign policy issue on which Turkey differs most significantly with the United States. ${ }^{72}$

Islamic parties that I have known are vocal on the Israel-Palestine conflict stating that Israel must withdraw from the occupied territories before talks. Most would like to have a peaceful resolution of the problem, as they do not want to see the continued injustice, occupation and human rights violations being perpetuated. ${ }^{73}$ When I posed the same question to the President of the PKS in Indonesia, he responded with reference to the Israel-Palestine conflict and emphasised his party's policy on the basis of a commitment of freedom and independence: "Under the Indonesian constitution and the Indonesian government, we stand with the independence movement and against any aggression or colonisation in the world; so we stand with this one [...]. Nothing changes in Palestine, no positive development [...]. So we stand with them [the Palestinians] until they get their independence in the near future, inshä'allāh." ${ }^{\prime 74}$

\section{Conclusions and Recommendations}

There has been a revival of interest in the maqasșid since the turn of the century. In the political context this has been driven by Islamic political leaders in response to internal domestic and external international dynamics. The AKP, PRK and PKS demonstrate the viability of Islamic democracy; they argue that Islamicoriented political parties can uphold both the principles of democracy and Islam while maintaining positive relations with both the Muslim world and the West. While Turkey's AKP has proven itself through democratic ascension to power and re-election without reference to Islam or Islamic concepts, the two other parties favour the maqāṣid approach more explicitly

- Collectively, these parties represent a second generation of Islamic-oriented political parties that are inspired by Islam and committed to advancing justice, human rights, good governance and economic prosperity in the interest of their respective people. They are not only redefining the concepts of Islamic democracy and political Islam but also the fate of Islam itself in the sociopolitical context.

- Additionally, these parties advocate positive relations with the West and their policies are mostly unopposed to those outlined in US foreign policy documents. However, they display a high level of self-confidence, are acutely aware of and responsive to the sentiments of their constituencies, and are 
disinclined to support US foreign policy where it is in disagreement with their values and principles.

For the United States, democracy and human rights form a minor, third pillar of foreign policy, dwarfed by the central pillars of stability of oil supplies and security of Israel. In the absence of any strategic value to the United States, religio-political reform is unlikely to hasten the United States' reluctant recovery from its aversion to political Islam.

- However, an embracing of a maqāșid approach in Muslim politics and governance should not be based on relations with the West but its benefits to Muslim states and societies in terms of promoting collective well-being, spiritual and material prosperity, and a reconnection with the essence of Islamic teachings.

\section{Notes}

1. Vali Nasr, "The Rise of Muslim Democracy", Journal of Democracy 16, no 2 (April 2005), 13.

2. Anthony Bubalo, Greg Fealy and Whit Mason, Zealous Democrats: Islamism and Democracy in Egypt, Indonesia and Turkey (Sydney: Lowy Institute for International Policy, 2008), 15.

3. Nasr, "The Rise", 13.

4. Lawrence Davidson, "American Foreign Policy and the Rise of Islamic Politics", Arab Studies Quarterly 31, no. 1 (Winter 2009), 5.

5. Irfan Ahmad, Islamism and Democracy in India: The Transformation of Jamaat-e-Islami (Princeton: Princeton University Press, 2009), 2.

6. Alex Glennie, "Building Bridges not Walls: Engaging with Political Islamists in the Middle East and North Africa", Institute for Public Policy Research (September 2009), 9.

7. Edward Said, Orientalism (London: Penguin Books, 1995), 1-5.

8. Mark Juergensmeyer, Global Rebellion: Religious Challenges to the Secular State, from Christian Militias to Al Qaeda (Berkeley: University of California Press, 2009), 10.

9. Steven Kull, "Public Opinion in the Islamic World on Terrorism, al Qaeda, and US Policies" (World Public Opinion.org, 25 February 2009, available at http://www.worldpublicopinion.org/pipa/pdf/ feb09/STARTII_Feb09_rpt.pdf(accessed on 17 September 2010).

10. Glennie, "Building", 38 .

11. See Fawaz Gerges, America and Political Islam (Cambridge: Cambridge University Press, 1999), 47-50; also see Glennie, "Building”, 9.

12. Gerges, America, 64 .

13. Elizabeth Hurd, "Political Islam and Foreign Policy in Europe and the United States", Foreign Policy Analysis 3 (2007), 348.

14. Gerges, America, 11.

15. Ibid., 63 .

16. Ibid., 64 .

17. Kamal Hassan, “The Influence of Maududi's Thought among Muslims in Southeast Asia: A Brief Survey”, The Muslim World 93 (July-October 2003), 444.

18. Irfan Ahmad, "Genealogy of the Islamic State: Reflections on Maududi's Political Thought and Islamism", Journal of the Royal Anthropological Institute (2009), 154.

19. Ibid., 155.

ICR 2.2 Produced and distributed by Pluto Journals ICR.plutojournals.org 
20. Hassan, "The Influence", 431-7.

21. Louay Safi, "The Islamic State: A Conceptual Framework", The American Journal of Islamic Social Sciences 8, no. 2 (1991), 227.

22. Ibid., 227.

23. Ibid., 231-3.

24. Nasr, "The Rise", 14.

25. Ahmad Fauzi Abdul Hamid, "Islamist Realignment and the Rebranding of the Muslim Youth Movement of Malaysia”, Contemporary Southeast Asia 30, no. 2 (August 2008), 222.

26. William Case and Liew Chin-Tong, "How Committed is PAS to Democracy and How Do We Know It?", Contemporary Southeast Asia 28, no. 3 (December 2006), 389.

27. Robert Hunt, "Can Muslims Engage in Interreligious Dialogue? A Study of Malay Muslim Identity in Contemporary Malaysia", The Muslim World 99, no. 4 (October 2009), 597.

28. Case and Liew, "How Committed is PAS", 386-8.

29. Hunt, "Can Muslims Engage”, 595.

30. Anwar Ibrahim, "Universal Values and Muslim Democracy”, Journal of Democracy 17, no. 3 (July 2006), 7.

31. Interview with Dr Muhammad Nur Manuty in Kuala Lumpur on 5 February 2010.

32. Islamic Party of Malaysia (PAS), "The Islamic State Document", available online at http://khazanahnasional.files.wordpress.com/2006/10/the_islamic_state_document.pdf(accessed on 17 September 2010).

33. Olivier Roy, The Failure of Political Islam (London: I.B. Tauris, 1994).

34. Olivier Roy, Globalised Islam: The Search for a New Ummah (New York: Columbia University Press, 2004), 1-2.

35. Fazlur Rahman, Major Themes of the Qur'ān (Kuala Lumpur: Islamic Book Trust, 1989), 62.

36. Graham Fuller, The Future of Political Islam (New York: Palgrave Macmillan, 2003), 198.

37. Ibid., 198 .

38. Ibid., 201 .

39. Edward Djerejian, "The US, Islam, and the Middle East in a Changing World" (2 June 1992) available online at http://www.disam.dsca.mil/pubs/Vol\%2014_4/Djerejian.pdf (accessed on 10 January 2010).

40. Ibid.

41. Ibid.

42. Ibid.

43. Gerges, America, 84.

44. Ibid., 85 .

45. Ibid., 103.

46. Ibid., 90 .

47. Ibid., 50 .

48. George Bush, “Text of President Bush's 2002 State of the Union Address" (29 January 2002), available online at http://www.washingtonpost.com/wp-srv/onpolitics/transcripts/sou012902.htm (accessed on 10 January 2010).

49. Barack Obama, "Inauguration Speech" (20 January 2009), available online at http://news.bbc. co.uk/2/hi/americas/obama_inauguration/7840646.stm (accessed on 10 January 2010).

50. Barack Obama, "Remarks by the President on a New Beginning", White House (4 June 2009), available online at http://www.whitehouse.gov/the press_office/Remarks-by-the-President-atCairo-University-6-04-09/ (accessed on 12 February 2010).

51. Ibid.

52. See Halim Rane, Reconstructing Jihad amid Competing International Norms (New York: Palgrave Macmillan, 2009), 159-201; and Islam and Contemporary Civilisation: Evolving Ideas, Transforming Relations (Carlton: Melbourne University Press, 2010), 75-99.

53. See Mohammad Hashim Kamali, An Introduction to Shariah (Kuala Lumpur: Ilmiah, 2006); Tariq Ramadan, Radical Reform (Oxford: Oxford University Press, 2008); Mashood Baderin, 
International Human Rights and Islamic Law (Oxford: Oxford University Press, 2005); and Rane, Reconstructing Jihad and Islam and Contemporary Civilisation.

54. Ahmad Raysuni, Imam al-Shatibi's Theory on the Higher Objectives and Intents of Islamic Law (Kuala Lumpur: Islamic Book Trust, 2006), 38-45.

55. Kamali, An Introduction, 118.

56. Muhammed Khalid Masud, Shatibi's Philosophy of Islamic Law (Kuala Lumpur: Islamic Book Trust, 1995), 86 .

57. Ibid.

58. AbdulHamid AbuSulayman, Towards an Islamic Theory of International Relations (Herndon: International Institute of Islamic Thought, 1993), 77.

59. Rane, Islam and Contemporary Civilisation, 47-8.

60. Hakan Yavuz, Secularism and Muslim Democracy in Turkey (Cambridge: Cambridge University Press, 2009), 3.

61. Interviews conducted with senior members of the AKP in Istanbul in February 2010.

62. Justice and Development Party, "Political Program", AK Parti Official Website, available online at http://eng.akparti.org.tr/english/partyprogramme.html (accessed on 17 September 2010).

63. On Turkey's pre-2002, i.e. pre-AKP ambitions, however, see Christoph Marcinkowski, "Leaving the Gazi's Path: Turkey's Evaporating Eastern Dreams" [review of Idris Bal, Turkey's Relations with the West and the Turkic Republics: The Rise and Fall of the Turkish Model (Aldershot and Burlington: Ashgate Publishing Ltd, 2000)], Journal of Diplomacy and Foreign Relations 3, no. 1 (2001), 104-7.

64. On this, and related issues, see also Christoph Marcinkowski, "Between 'Turkish Delights and Eurabia': The Islamic World and Europe at the Crossroads", in Christoph Marcinkowski (ed.), The Islamic World and the West: Managing Religious and Cultural Identities in the Age of Globalization, Freiburg Studies in Social Anthropology 24 (Vienna: LIT Verlag, 2009), 17-37.

65. Justice and Development Party, "Political Program".

66. Interview with Dr Muhammad Nur Manuty in Kuala Lumpur on 5 February 2010.

67. Interview with Luthfi Hasan Ishaaq in Jakarta on 9 April 2010.

68. Interview with Dr Muhammad Nur Manuty in Kuala Lumpur on 5 February 2010.

69. Interview with Luthfi Hasan Ishaaq in Jakarta on 9 April 2010.

70. Interview with Syed Husin Ali in Kuala Lumpur on 3 February 2010.

71. Interview with Luthfi Hasan Ishaaq in Jakarta on 9 April 2010.

72. Interview with Hüseyin Kansu in Istanbul on 8 February 2010.

73. Interview with Syed Husin Ali in Kuala Lumpur on 3 February 2010.

74. Interview with Luthfi Hasan Ishaaq in Jakarta on 9 April 2010. 